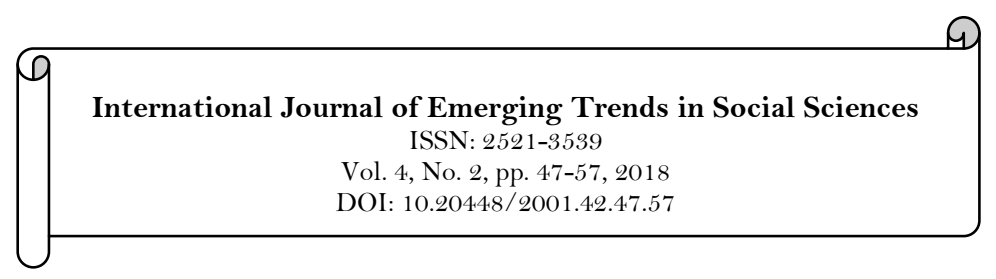

Uapdates

\title{
Comparative Analysis of Mass Media Coverage of the Fight Against Corruption in Nigeria by the Obasanjo and Buhari Administrations
}

\author{
Patrick Ene Okon ${ }^{1}$ \\ ${ }^{1}$ Department of Mass Communication and Digital Media, University of Calabar, Calabar, Nigeria \\ Email:eneokon@yahoo.com
}

\begin{tabular}{|c|c|}
\hline Abstract & \\
\hline $\begin{array}{l}\text { Since Nigeria returned to democratic governance in May 1999, the } \\
\text { fight against corruption has been a major preoccupation of every } \\
\text { administration in the country. This paper comparatively analysed the } \\
\text { frequency, prominence and depth of coverage given to this "fight" by } \\
\text { the Nigerian media during the administrations of former President } \\
\text { Olusegun Obasanjo (1999-2007) and incumbent President } \\
\text { Muhammadu Buhari (2015- date). Content analysis was the } \\
\text { research instrument used to generate data. For Obasanjo era, } 39 \\
\text { issues each of The News and TELL magazines selected through } \\
\text { systematic sampling technique from the first three years of the } \\
\text { administration were used; while for Buhari era, } 26 \text { issues each of two } \\
\text { newspapers - the privately-owned Sun, and State Government- } \\
\text { owned Nigerian Chronicle - were selected from within the first six } \\
\text { months of } 2017 \text { based on the composite week sampling technique. } \\
\text { Content categories of editorial items on corruption used were } \\
\text { bribery, forgery/perjury, fraud, misappropriation and } \\
\text { mismanagement, while units of analysis were news, } \\
\text { features/opinions/columns, editorials, photographs/cartoons, } \\
\text { advertorials, and letters to editor. Attention score was on } \\
\text { prominence, depth, frequency, and slant. Theoretical framework } \\
\text { anchored on the Agenda-Setting Theory. Research findings from } \\
\text { each segment of the study were descriptively discussed and } \\
\text { comparatively analysed using frequency count, attention score and } \\
\text { percentage mean. It was concluded that the trends in media coverage } \\
\text { under the two administrations were similar. Recommendations made } \\
\text { included: that the media should be more consistent, persistent and } \\
\text { responsible in their coverage of anti-corruption issues; while the } \\
\text { government should be more proactive and all-inclusive in the fight } \\
\text { against corruption. }\end{array}$ & $\begin{array}{l}\text { Keywords: } \\
\text { Buhari administration } \\
\text { Corruption } \\
\text { Media coverage } \\
\text { Fight against corruption } \\
\text { Mass media } \\
\text { Obasanjo administration. } \\
\text { Licensed: } \\
\text { This work is licensed under a } \\
\text { Creative Commons Attribution } \\
\text { 4.0 License. } \\
\text { Publisher: } \\
\text { Scientific Publishing Institute }\end{array}$ \\
\hline
\end{tabular}

\section{Introduction}

Nigeria and corruption are like Siamese twins - conjoined and difficult to separate! Corruption in Nigeria has, therefore, been so endemic and precarious that in 1997, Vision 2010 Committee (1997) aptly observed in its main report:

Corruption pervades all facets of the society including the political realm. Although corruption is a worldwide phenomenon, the level of corruption and the brazen disregard for rules and regulations in Nigeria have impacted negatively on the nation's development and external image. Corruption appears to have become a way of doing things, though it is resented by a significant number of people. The ordinary Nigerian appears helpless in the face of weak and selective applications of sanctions against perpetrators since the law enforcement agencies have themselves become infected with corruption. Political corruption has also attained very sophisticated levels in Nigeria.... 
Based on this observation, the committee admitted, “The net effect of corrupt practices is that Nigeria's image today is less satisfactory, to say the least." Unfortunately, a couple of years after this very damning report, the rot in government got messier. Many top officials of government became even more involved, one way or the other, in corrupt activities.

On July 5, 1999, Newswatch magazine carried a cover story captioned, "Looting of the States," which exposed the brazen way the former military administrators of Delta, Kogi, Cross River, Edo, Imo, Benue, Enugu, Ogun, Nassarawa, Adamawa, Lagos, Oyo and Borno States looted their state coffers, even a few days to the end of their respective tenures. They were each accused of awarding questionable contracts, engaging in reckless and meaningless expenditures, maladministration, and outright stealing of public property.

On July 10, 1999, The News magazine startled the nation with its cover story titled, "Face of a Liar," in which it reported that the former speaker of the Federal House of Representatives, Alhaji Ibrahim Salihu Buhari, had fraudulently forged his bio-data and a University of Toronto business degree. Attempts by the disgraced number four citizen of Nigeria to hold on to his position did not succeed as he was forced to resign from his position and the House on July 22, 1999. He was later arrested, arraigned before a magistrate court and convicted accordingly.

The then number three citizen and president of the Senate of the Federal Republic of Nigeria, late Chief Evans Enwerem, was not spared a mention in the prevailing fraudulent dealings. Tell magazine, in its August 9, 1999 issue, published details that the late chief or his half-brother might have been convicted of stealing by a court of defunct Eastern Nigeria in 1945. Later issues of the magazine further accused him of deliberate falsification of his age and inconsistency in the records of schools he attended. This caused him to lose his position as Senate president. His successor, late Dr Chuba Okadigbo, was also removed after a few months in office for alleged corrupt practices.

The former governor of Lagos State and currently, national leader of the ruling All Progressives Congress (APC), Senator Bola Tinubu, was also accused by Today newspaper of lying on oath about the schools he attended. The case brought up by late Chief Gani Fawehinmi on whether the then governor could be investigated by the police generated a lot of controversies. Even, the media got enmeshed in the Tinubu's perjury saga to such an extent that Galadima (2003) noted that there were "accusations of sectional bias levelled against Southern news media in their neglect of Governor Tinubu's forgery case and their concentration on Salihu Buhari and Evans Enwerem's cases...”

Other serving top political office holders who were also accused by the media of one corrupt practice or the other included the former governor of Kogi State, late Prince Abubakar Audu, the then governor of Abia State, Dr Orji Uzor Kalu, the former governor of Delta State, Chief James Ibori, and some cabinet ministers. Even on March 20, 2000, The News carried a cover story titled, "The Looting of PTF: By Obasanjo's Men." In the report, the magazine alleged impropriety, misconduct, and corruption against members of the interim management committee headed by Dr. Haroun Adamu, which was set up by the then president, Chief Olusegun Obasanjo, to wind up the activities of the Petroleum (Special) Trust Fund.

Several other cases of corruption were levelled against very top public officers including the former head of state, late General Sani Abacha, his ministers, aides and family members who were accused of stealing several billions of naira and a lot more in hard currency. There were reports confirming seizure of some property corruptly acquired by them and repatriation of huge sums of money lodged by them in foreign banks. Even his successor, General Abdulsalam Abubakar, was accused of running a "Provisional Looting Council" during his 11-month stay as head of state.

The situation became more worrisome and may be absolutely impossible for human beings to address that religious leaders took the matter before the spiritual court for succour. For instance, in 1995, the Catholic Bishops Conference of Nigeria $(\mathrm{CBCN})$ composed a "prayer against bribery and corruption in Nigeria" while the Pentecostal Fellowship of Nigeria (PFN) held several prayer sessions, all aimed at rescuing the country from this hydra-headed monster.

This was the precarious situation Nigeria found itself when the country returned to democratic governance in May 1999 after many years of military interregna! Since then, fighting against corruption became one of the major preoccupations of every elected administration in the country. As McLuhan (1994) has indicated, “The medium is the message." This paper's major aim, therefore, is to comparatively analyse the frequency, prominence and depth of coverage given to this "fight" by the Nigerian media during the administrations of former President Olusegun Obasanjo (1999 - 2007) and the incumbent, President Muhammadu Buhari (2015 - date).

\section{Objectives of the Study}

In an attempt to find the solution to the problem under investigation, the following objectives were drawn up:

(i) To determine the frequency and prominence given to the coverage of the anti-corruption campaign in Nigeria by the print media during the administrations of Presidents Obasanjo and Buhari;

(ii) To find out the extent to which the selected print media treated anti-corruption issues in their coverage during the two administrations; and. 
(iii) To determine what other influences affected the editorial consideration of the selected newsmagazines and newspapers in the coverage of the anti-corruption campaign in Nigeria.

\section{Research Methodology}

Content analysis was the research instrument used to generate data for this paper. For the Obasanjo era, 39 editions each of The News and TELL magazines selected through systematic sampling technique from the first three years of the administration were used; while for the Buhari era, 26 issues each of two newspapers the privately-owned Sun, and State Government-owned Nigerian Chronicle - were selected from within the first six months of 2017 based on the composite week sampling technique.

Content categories of editorial items on corruption used for media coverage in the two eras were bribery, forgery/perjury, fraud, misappropriation and mismanagement, while the units of analysis were news, features/opinions/columns, editorials, photographs/cartoons, advertorials, and letters to the editor. Attention score was on prominence, depth, frequency, and slant (or direction). Coding sheet was used to document the frequency of anti-corruption reports.

An inter-coder reliability test was done, using three mass communication lecturers as independent coders who coded the sampled content according to the coding instructions prepared for this study. Their results showed a high level of agreement at .85, thereby confirming the reliability of the research instrument designed for the study.

Research findings from each segment of the study were descriptively discussed and comparatively analysed using frequency count, attention score and percentage mean.

\section{Theoretical Framework}

The conceptual framework for this study anchored on the Agenda-Setting Theory, which "posits a relationship between the way the media rank the importance of various issues published in them and degree of salience these issues have for the society" (Okon, 2004). However, before explaining further on the theory, it is necessary to consider two scenarios on the society's perception of the media as painted by some wellestablished communicators.

First, Cassata and Asante (1979) while discussing on the power of the press theory, give the following assessment of the media in the eyes of the people:

For years after the World War II, popular thinking ascribed powerful influence to the press. The audience was thought of as a sitting target waiting to be shot at. The stimulus was the message carried by the press; the response was the outcome of the audience's complete belief in the press as authority. Something was true because the press said so....

Even though the media are considered this powerful, it is not always that they are seen in such light. The second scenario is drawn from the comments of Fink (1996):

Polls reveal many negatives in public perception of the press. And, contrary to long-held industry belief, polls show the criticism is not simply of the press as a messenger of bad tidings but rather as an impersonal, arrogant and manipulative element that intrudes into political, social and economic life. The press often is seen as a self-appointed participant in not merely an observer of - the decision-making process. And some critics ask: who elected the press to run our life?

The above views describe the different ways some people perceive the role the media play in shaping opinion in the society. One theory that is very popular in this regard and which many researchers on mass communication issues, especially on the effect of the media on society, have done a lot of studies on is the Agenda-setting Theory.

Rooted in the Power of the Press Theory and closely related to the Gate-keeping concept, the Agendasetting theory confers on the media the ability to choose and emphasise certain topics thereby causing the society to see the topics as important. For example, a case of an office messenger stealing one million naira from his master can be over-orchestrated and positioned as a national issue by the media through frequent media commentary and exposure, while a story of an influential senator misappropriating 10 billion naira can be reduced to a minor infraction of the law if the media choose not to give it adequate coverage.

Adding credence to this argument on the media as a powerful agenda-setter in the society, Cohen (1963) succinctly explains, "The press may not be successful much of the time in telling the people what to think but it is stunningly successful in telling its readers what to think about." And this is exactly what the media have been able to do as can be seen in some studies carried out by researchers on some issues relating to agendasetting functions of the media. Their contributions will help us understand this theory better.

In a longitudinal study of agenda-setting for the issue of environmental pollution carried out by Ader in Journalism and Mass Communication Quarterly (Ader, 1995) the findings suggest that the amount of media attention devoted to pollution influences the degree of public salience for the issue. The report continues,

This is consistent with previous findings by researchers that the environment is an unobtrusive issue, an issue that does not have tangible consequences for individuals. 
Therefore, the public has little personal contact with pollution and so relies on the media for information.

Also making crucial contributions, McCombs and Shaw published their two major research findings titled "the Agenda-setting Functions of Mass Media" in McCombs and Shaw (1972) and "Structuring the "Unseen Environment" in the Journal of Communication (Spring, 1976). Their comments, as contained in the 1976 report, say,

Audiences not only learn about public issues and other matters through the media, they also learn how much importance to attach to an issue or topic from the emphasis the mass media place upon it. For example, reflecting what candidates are saying during campaign the media apparently determine the important issue. In other words, the mass media set the 'agenda' for the campaign.

McCombs and Shaw also present the model to illustrate this assertion that the media's ability to affect cognitive change among individuals is one of the most important aspects of the power of mass communication.

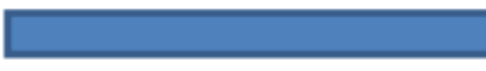

$\mathrm{X} 2$

$\mathrm{Xs}$

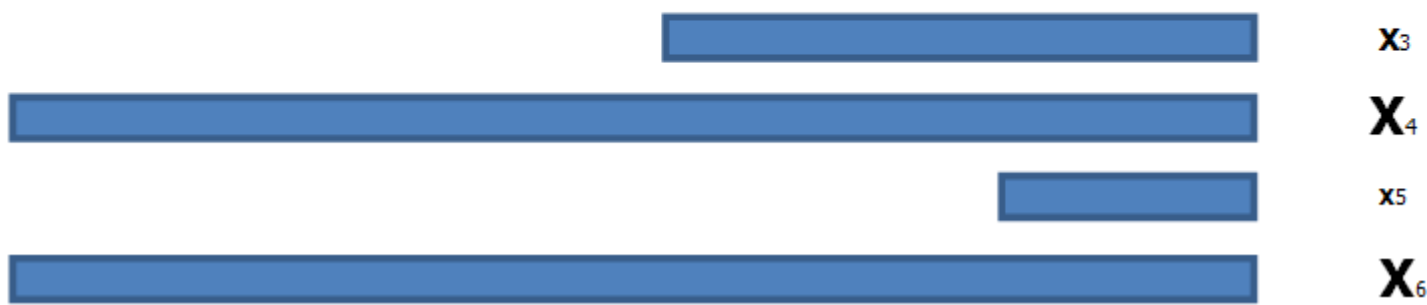

$\mathrm{X} 6$

Figure-1. McCombs and Shaw's agenda-setting model of media effects, 1976

Source: Watson and Hill (1993).

According to this model, there is a direct correlation between the amount of media exposure to $\mathrm{X}$ (the issue) and the degree of importance the public attaches to the issues (X). The media exposure of issues $\mathrm{X} 1, \mathrm{X} 4$, and $\mathrm{X} 6$ are so much that the public perceives them as very important while issue $\mathrm{X} 5$ receives the least media attention and, therefore, is considered by the public as being the least important. Even though many communication experts have seen this model as having oversimplified media effects, the fact remains that it has helped us in an illustrative form to appreciate the impact of the agenda-setting function of the media on society.

The Agenda-setting theory formed the basis of this study. It helps to place the media in a proper perspective to set the agenda for an all-encompassing war against corruption. Also, its tenets are what guide the principles of this paper and lay the necessary foundation for the study on media coverage of anticorruption in Nigeria.

\section{Mass Media and the Fight against Corruption in Nigeria}

Corruption, according to Macrea (1982) and cited by Ayodele (2012) is an arrangement where there is an exchange between two parties - the demander and the supplier - which "(i) has an influence on the allocation of resources either immediately or in the future; and (ii) involves the use or abuse of public or collective responsibility for private ends." The nefarious activities of corrupt people and entities can be exposed using the mass media. In this wise, the media, as opined by Touitou (2016) have the capacity to raise public awareness about illegal and corrupt activities of public officers, expose the causes and effects of corruption, and proffer solution to corruption. Our focus in this paper is on how the war against corruption has been fought and the role of the media in reporting the success or otherwise of the war during the administrations of Obasanjo and Buhari - both retired army generals and one-time military heads of state in Nigeria.

The Olusegun Obasanjo Era:

Shortly before the swearing-in of Chief Olusegun Obasanjo as Nigeria's elected president on May 29, 1999, the country was neck deep in corruption. Transparency International, the anti-corruption organisation Obasanjo co-founded, had twice in its Corruption Perception Index (CPI) ranked Nigeria as the most corrupt nation in the world. The president's inaugural speech on that day triggered the heightened campaign against corruption in Nigeria. He had elaborately said,

Corruption is incipient in all human societies and in most human activities. But it must not be condoned. This is why laws are made and enforced to check corruption, so that society would survive and develop in a reasonable and predictable way. No society can achieve 
anything near its full potential if it allows corruption to become full blown cancer it has become in Nigeria. One of the greatest tragedies of military rule in recent times is that corruption was allowed to grow unchallenged, and unchecked.... The rules and regulations for doing official business were deliberately ignored, set aside or by-passed to facilitate corrupt practices. The beneficiaries of corruption in all forms will fight back with all the foul means at their disposal. We shall be firm with them. There will be no sacred cows. Nobody, no matter who and where will be allowed to get away with the breach of the law or the perpetration of corruption and evil....

To strengthen the existing laws on anti-corruption, including the Penal Code Act (for Northern Nigeria), Criminal Code Act (for Southern Nigeria), Code of Conduct Bureau and Tribunal Act of 1991, Banks and Other Financial Institutions (Amendment) Act of 1991, and Failed Banks (Recovery of Debts) and Financial Malpractices in Banks (Amendment) Act of 1994, the Obasanjo administration passed:

- The Independent Corrupt Practices and Other Offences Act, 2000, which set up the Independent Corrupt Practices Commission (ICPC) to tackle corruption in the public sector;

- Economic and Financial Crimes Commission (EFCC) Act, 2004 that gives power to EFCC to investigate people from all sectors of life who appear to live above their legitimate means;

- Advance Fee Fraud and Other Related Offences Act, 2006, which prohibits and punishes the act of obtaining money/property by false pretence, etc.;

- Nigerian Extractive Industries Transparency Initiative (NEITI) Act, 2007, which seeks to promote transparency and accountability in the management of Nigeria's oil, gas and mining revenues.

Even with the reinvigorated war against corruption in Nigeria, the menace continued to grow in leaps and bounds. The media were always awash with reports of one public officer or the other involved in corrupt practices. Apart from the cases of those public officers earlier mentioned in this paper, the media, according to Yusha'u (2009) had a field day pursuing and revealing many more interesting allegations of corruption and other wrongdoings by public office holders that had attracted rapt public attention. During the Obasanjo administration, such other reports included those involving the then Vice President Atiku Abubakar, exSenate President Adolphus Wabara, former House of Representatives speaker, Patricia Olubumi Etteh, and her deputy, Babangida Nguruje, the former inspector-general of police, Mr Tafa Balogun, the then chairman of Osun State Election Tribunal, Justice Thomas Narvon, and members of his tribunal, former federal cabinet ministers, Professor Fabian Osuji (Education), Professor Adenike Grange, Mr Gabriel Aduku (Health), daughter of the president, Senator Iyabo Obasanjo-Bello, and the Halliburton business scam, to mention a few.

Unfortunately, in an apparent negation of his promises that "there will be no sacred cows" and that "nobody, no matter who and where, will be allowed to get away with the breach of the law or the perpetration of corruption," no concerted effort was made by the Federal Government under President Obasanjo to prosecute and obtain judgment against these and other high-profile officials alleged of corruption. Rather, the country only managed to graduate to the second most corrupt nation in the world in 2001, 2002 and 2003; and in the last year of his presidency, the world's corruption index saw Nigeria placed on an "improved" position as the $21^{\text {st }}$ most corrupt nation (Akor, 2014).

That was the sordid state of the war against corruption in Nigeria as bequeathed by President Obasanjo to his successor in office!

\section{The Muhammadu Buhari Era:}

Sandwiched between Obasanjo and Buhari was the Umaru Yar'Adua/Goodluck Jonathan administration during whose tenure the Fiscal Responsibilities Act 2010, Freedom of Information Act 2011, and Money Laundering (Prohibition) (Amendment) Act 2012 were passed. However, this paper has not included this period within its scope of research.

Muhammadu Buhari, whose presidency constitutes the more current flank of this study, had predicated his electioneering campaign on the "Change Agenda," which he said would turn Nigeria into:

A country that you can be proud of at anytime and anywhere; where corruption is tackled; where your leaders are disciplined and lead with vision and clarity; where the stories that emerge to the world from us are full of hope and progress (The Nation, 2015).

Having been inundated with the debilitating effects of corruption on the national psyche, most Nigerians readily bought into the "change" mantra of Buhari and his political party - the All Progressive Congress (APC). He won the presidency and at his inauguration, the new Nigerian president did not forget to include corruption in his speech. He referred to it as "pervasive corruption" and made a promise to tackle it "head on." He also gave the assurance, "Nigerians will not regret that they have entrusted national responsibility to us.... We can fix our problems." All this was declared on May 29, 2015!

More than three years down the line, how has the Buhari administration tackled corruption? To start with, it has introduced one major piece of legislation - the Nigeria Whistle Blower Act, 2016 - to protect persons making public-interest disclosure related to an act of corruption, misuse of power, or criminal offense by a public servant. Through it, N29.2billion has, as at April 2018, been recovered by the Federal Government (Signature, 2018). Another plus is the implementation of the Treasury Single Account (TSA) policy for all 
MDAs which, according to Finance Minister Kemi Adeosun, has eliminated ghost workers and saved for Nigeria N68billion from personnel cost (Next Edition, 2018). Also, scores of top Nigerians have been prosecuted for corruption, and they include Steve Orosanye, former head of federal civil service, Alison Madueke, former minister of petroleum, Abdulrasheed Maina, former chairman of pension reform taskforce, Femi Fani-Kayode, former minister of aviation, Aziaola Robert, cousin of former President Jonathan, Sambo Dasuki, former national security adviser to President Jonathan, Alex Badeh, former chief of defence staff, Raymond Dokpesi, chairman of Africa Independent Television (AIT), Patrick Akpobolokemi, former directorgeneral of Nigerian Maritime and Safety Agency (NIMASA), Olabode George, former deputy chairman of the opposition Peoples Democratic Party (PDP), and Olisa Metuh, former PDP national publicity secretary.

Besides, according to the 2016 corruption index, Nigeria for the first time in 16 years was not among the top-10 most corrupt countries in the world (Transparency International, 2016). In that same year, Nigeria moved up in World Bank's Ease of Doing Business Index (World Bank Group, 2017) and at the 30 ${ }^{\text {th }}$ ordinary session of African Union's Heads of State and Government in Addis Ababa in January 2018, President Buhari was named as the first ever "anti-corruption champion in Africa" (Africa News, 2018).

In spite of these seeming successes in the war against corruption by President Buhari, so much dark clouds have remained to eclipse the campaign's success story. For instance, there are still media reports of embezzlement, bribery, misappropriation, fraud, etc. involving public officers currently in service. Examples: the alleged mismanagement of N28billion meant for the rehabilitation of Internally Displaced Persons (IDPs) in the North-East by the Office of the Secretary to Government of the Federation, Babachir Lawal, and the Presidential Initiative on North-East (PINE), N3obillion fraud in the Nigerian Social Insurance Trust Fund (NSTIF), N84 billion illegally spent from the National Health Insurance Scheme (NHIS) by the Federal Government, \$25billion scam in Nigerian National Petroleum Corporation (NNPC), N12obillion fraud by the inspector-general of police, Ibrahim Idris, etc. Unfortunately, nothing substantial has been done by the Government about all these allegations. Maybe this is why things have been getting worse in the country's fight against corruption, with Transparency International placing the country on No. 148 out of 180 countries surveyed in its 2017 corruption perception index - disheartening 12 places below where it was just a year earlier (Transparency International, 2017). In fact, every arm and tier of government in Nigeria has been reported as being involved in one corrupt activity or the other. State and Local Governments are not exempted; the nation's legislature is accused to be terribly infested with it; and even the judiciary, which is supposed to be the last bastion of hope for the people, has also been embroiled in this unwholesome practice. According to the current chief justice of Nigeria, Justice Walter Onnoghen, corruption in the judiciary is not limited to bribe-taking but includes the giving of judgments or orders based on considerations other than legal merits. He maintains that "a corrupt judge is not only a disgrace to the Bench and the noble profession, but also a disaster to the course of justice and the nation" (Vanguard, 2018). However, many analysts have persistently insisted that the Buhari administration's anti-corruption war is only being waged against opponents of the APC-led Government. Their stand is based on the lukewarm attitude of federal anticorruption agencies towards officials under investigation or even indicted for certain corrupt practices who are members of or have decamped from PDP to the ruling party; in direct contrast to the stringent stance of these agencies to haunt, arrest, detain, and/or prosecute those alleged corrupt officials still remaining in the opposition political party. As aptly suggested by Oyibode (2017) “... for Buhari to win the confidence of Nigerians in his anti-corruption fight, it must be holistic, regardless of tribe, religion and party affiliations.”

\section{Data Presentation}

For the media coverage of anti-corruption campaign under the Obasanjo administration, the two newsmagazines - The News and TELL - were individually content-analysed and the average percentage scores used. The same was applied for the two sampled newspapers - The Sun and Nigerian Chronicle - used to assess media coverage of the campaign during the Buhari era. From the separate content analyses carried out, lots of data were generated as presented below:

Table-1. Distribution of editorial items by categories of anti-corruption reports

\begin{tabular}{l|l|l|l|l}
\hline \multirow{2}{*}{$\begin{array}{l}\text { Category of Anti- } \\
\text { Corruption }\end{array}$} & Obasanjo Administration & \multicolumn{2}{l}{ Buhari Administration } \\
\cline { 2 - 5 } & Frequency & Average \% & Frequency & Average \% \\
\hline Bribery & 6 & 5.27 & 12 & 7.02 \\
\hline Forgery/Perjury & 17 & 14.91 & 15 & 8.77 \\
\hline Fraud & 36 & 31.58 & 61 & 35.67 \\
\hline Misappropriation & 17 & 14.91 & 24 & 14.04 \\
\hline Mismanagement & 38 & 33.33 & 59 & 34.50 \\
\hline Total & $\mathbf{1 1 4}$ & $\mathbf{1 0 0}$ & $\mathbf{1 7 1}$ & $\mathbf{1 0 0}$ \\
\hline
\end{tabular}

For this study, five forms of corruption were identified and used in this study. In this table, it can be seen that under both administrations, the distribution of anti-corruption reports were slightly different in the sampled publications. Of the 114 stories published during Obasanjo era, $33.33 \%$ of them were on 
mismanagement, followed by $31.58 \%$ for fraud, $14.91 \%$ each for forgery/perjury and misappropriation, and only $5.27 \%$ for bribery. During Buhari era, on the other hand, out of the 171 stories published, fraud was number one with $35.67 \%$, followed by mismanagement (34.5\%), misappropriation (14.04\%), forgery/perjury $(8.77 \%)$, and bribery $(7.02 \%)$.

Table-2. Distribution of anti-corruption stories by units of analysis in the respective publications.

\begin{tabular}{l|l|l|l|l}
\hline \multirow{2}{*}{$\begin{array}{l}\text { Unit of Analysis of Anti- } \\
\text { Corruption Reports }\end{array}$} & Obasanjo Administration & \multicolumn{2}{l}{ Buhari Administration } \\
\cline { 2 - 5 } & Frequency & Average \% & Frequency & Average \% \\
\hline News stories & 67 & 58.77 & 112 & 65.50 \\
\hline Editorials & 4 & 3.51 & 1 & 0.58 \\
\hline Features/opinions/columns & 11 & 9.65 & 28 & 16.37 \\
\hline Pictures/drawings/cartoons & 18 & 15.79 & 16 & 9.36 \\
\hline Letters to the editor & 9 & 7.89 & 10 & 5.85 \\
\hline Advertorials & 5 & 4.39 & 4 & 2.34 \\
\hline Total & $\mathbf{1 1 4}$ & $\mathbf{1 0 0}$ & $\mathbf{1 7 1}$ & $\mathbf{1 0 0}$ \\
\hline
\end{tabular}

For the distribution of editorial items by unit of analysis, the following order was recorded: during the Obasanjo era - news stories (58.77\%), pictures/drawings/cartoons (15.79\%), features/opinions/columns (9.65\%), letters to the editor (7.89\%), advertorials (4.39\%), and editorials (3.51\%); features/opinions/columns six $(17.14 \%)$ while for Buhari era, a slightly different order was identified: news stories (65.5\%), features/opinions/columns (16.37\%), pictures/drawings/cartoons (9.36\%), letters to the editor (5.85\%), advertorials $(2.34 \%)$, and editorials $(0.58 \%)$.

Table-3. Prominence of anti-corruption stories as reported in the publications.

\begin{tabular}{|c|c|c|c|c|c|c|c|c|}
\hline \multirow{2}{*}{$\begin{array}{l}\text { Prominence/ } \\
\text { Placement of } \\
\text { Editorial Items }\end{array}$} & \multicolumn{4}{|c|}{ Obasanjo Administration } & \multicolumn{4}{|c|}{ Buhari Administration } \\
\hline & Frequency & $\%$ & $\begin{array}{l}\text { Attention } \\
\text { Score }\end{array}$ & $\%$ & Frequency & $\%$ & $\begin{array}{l}\text { Attention } \\
\text { Score }\end{array}$ & $\%$ \\
\hline Front/cover page & 29 & 25.44 & 87 & 37.83 & 19 & 11.11 & 57 & 20.88 \\
\hline Sectional/back page & 58 & 50.88 & 116 & 50.43 & 64 & 37.43 & 128 & 46.89 \\
\hline Any other page & 27 & 23.68 & 27 & 11.74 & 88 & 51.46 & 88 & 32.23 \\
\hline Total & 114 & 100 & 230 & 100 & 171 & 100 & 273 & 100 \\
\hline
\end{tabular}

From the above table, the prominence given by the sampled publications to anti-corruption reports during the two administrations are recorded. For the period of Obasanjo presidency: sectional page attracts the highest attention score of 116 or $50.43 \%$, cover page scores 87 or $37.83 \%$, and any other page has a score of 27 (11.74\%). Out of 171 anti-corruption stories published under Buhari, 64 (37.43\%) with a score of $128(46.89 \%)$ were on sectional/back pages; $88(51.46 \%)$ with a score of 88 or $32.23 \%$ were for any other pages; while 19 ( $11.11 \%)$ with 57 attention score or $20.88 \%$ were on front/cover pages.

Table-4. Distribution of length of anti-corruption stories in pages/columns of sampled publications

\begin{tabular}{|c|c|c|c|c|c|c|c|c|}
\hline \multirow{2}{*}{$\begin{array}{l}\text { Length of Anti- } \\
\text { Corruption Stories }\end{array}$} & \multicolumn{4}{|c|}{ Obasanjo Administration } & \multicolumn{4}{|c|}{ Buhari Administration } \\
\hline & Frequency & $\%$ & $\begin{array}{l}\text { Attention } \\
\text { Score }\end{array}$ & $\%$ & Frequency & $\%$ & $\begin{array}{l}\text { Attention } \\
\text { Score }\end{array}$ & $\%$ \\
\hline Every full page & 298 & 88.43 & 894 & 94.21 & 32 & 18.71 & 96 & 47.53 \\
\hline Half page & 19 & 5.64 & 38 & 4.00 & 33 & 19.30 & 66 & 32.67 \\
\hline Quarter page & 17 & 5.04 & 17 & 1.79 & 40 & 23.39 & 40 & 19.80 \\
\hline Less than 2 columns & 3 & 0.89 & $\mathrm{O}$ & $\mathrm{O}$ & 66 & 38.60 & $\mathrm{O}$ & $\mathrm{O}$ \\
\hline Total & 337 & 100 & 949 & 100 & 171 & 100 & 202 & 100 \\
\hline
\end{tabular}

Table 4 seeks to determine the distribution of anti-corruption reports in the pages/columns of the sampled publications. Every full page attracts an attention score of three, half page attracts two points, quarter page attracts one point, and less than two columns receive no point. For Obasanjo administration, the sampled publications jointly devoted 298 full pages (88.43\%), 19 half pages (5.64\%), 17 quarter pages (5.04\%) and only three on less than two columns $(0.89 \%)$ to anti-corruption stories. The full, half and quarter pages, with a total attention score of $949(100 \%)$, were considered prominent while the three stories on less than two columns had an attention score of zero. For Buhari era, 66 stories or $38.6 \%$ were placed on less than two columns, 40 $(23.39 \%)$ on quarter pages, $33(19.3 \%)$ on half pages and $32(18.71 \%)$ on full pages. However, when assessed on attention score basis, the order was completely reversed with full pages now leading the pack with a score of $47.53 \%$, followed by half pages $-32.67 \%$, quarter pages $-19.8 \%$ and less than two columns - zero (0.0\%). 
Table-5. Distribution of photographs/drawings used with anti-corruption stories.

\begin{tabular}{|c|c|c|c|c|c|c|c|c|}
\hline \multirow{2}{*}{$\begin{array}{l}\text { Use of } \\
\text { Photograph/ } \\
\text { Drawing }\end{array}$} & \multicolumn{4}{|c|}{ Obasanjo Administration } & \multicolumn{4}{|c|}{ Buhari Administration } \\
\hline & Frequency & $\%$ & $\begin{array}{l}\text { Attention } \\
\text { Score }\end{array}$ & $\%$ & Frequency & $\%$ & $\begin{array}{l}\text { Attention } \\
\text { Score }\end{array}$ & $\%$ \\
\hline Full page display & 21 & 7.37 & 63 & 34.05 & 5 & 4.63 & 15 & 13.51 \\
\hline Across half page & 51 & 17.89 & 102 & 55.14 & 10 & 9.26 & 20 & 18.02 \\
\hline Across 3 columns & -- & -- & -- & -- & 10 & 9.26 & 10 & 9.01 \\
\hline Across 2 columns & - & - & - & -- & 18 & 16.67 & 18 & 16.22 \\
\hline Single column & 193 & 67.72 & $\mathrm{O}$ & $\mathrm{O}$ & 17 & 15.74 & $\mathrm{O}$ & $\mathrm{O}$ \\
\hline Full colour & 20 & 7.02 & 20 & 10.81 & 48 & 44.44 & 48 & 43.24 \\
\hline Total & 285 & 100 & 185 & 100 & 108 & 100 & 111 & 100 \\
\hline
\end{tabular}

Table 5 depicts the distribution of photographs and drawings used to add depth and meaning to anticorruption stories. Every full-page display of photograph/drawing had an attention score of three, across half page had two, across three/two columns had one while across single column had zero score. The full-coloured picture had additional score of one. During Obasanjo presidency, 21 pictures/drawings (7.37\%), with attention score of 63 or $34.05 \%$ were on full pages; 51 (17.89\%), with a score of $102(55.14 \%)$ were across half pages; 193 $(67.72 \%)$ with zero attention score (or $0.0 \%)$ were carried on single columns. Twenty photographs or $7.02 \%$, with an attention score of $20(10.81 \%)$ were printed in full-colour process. For Buhari era, there were five photographs/drawings (4.63\%) published on full page with attention score of $15(13.51 \%)$. Both half page and across three columns recorded $10(9.26 \%)$, but had attention scores of $20(18.02 \%)$ and 10 (9.01\%) respectively; while the 17 illustrations published across single column (15.74\%) had a zero attention score (0.0\%). The 48 photographs published in full-colour, representing $44.44 \%$, had an attention score of 48 (43.24\%).

Table-6. Slant or direction of anti-corruption editorial items in the sampled publications

\begin{tabular}{l|l|l|l|l|l|l|l|l}
\hline $\begin{array}{l}\text { Slant or } \\
\begin{array}{l}\text { Direction of } \\
\text { Editorial Items }\end{array}\end{array}$ & \multicolumn{2}{|l|}{ Obasanjo Administration } & \multicolumn{4}{|c}{ Buhari Administration } \\
\cline { 2 - 11 } & Frequency & $\mathbf{\%}$ & $\begin{array}{l}\text { Attention } \\
\text { Score }\end{array}$ & $\mathbf{\%}$ & Frequency & $\mathbf{\%}$ & $\begin{array}{l}\text { Attention } \\
\text { Score }\end{array}$ & $\%$ \\
\hline Favourable & 66 & 57.90 & 198 & 70.72 & 101 & 59.06 & 303 & 64.88 \\
\hline Unfavourable & 17 & 14.91 & 51 & 18.21 & 47 & 27.49 & 141 & 30.19 \\
\hline Neutral & 31 & 27.19 & 31 & 11.07 & 23 & 13.45 & 23 & 4.93 \\
\hline Total & $\mathbf{1 1 4}$ & $\mathbf{1 0 0}$ & $\mathbf{2 8 0}$ & $\mathbf{1 0 0}$ & $\mathbf{1 7 1}$ & $\mathbf{1 0 0}$ & $\mathbf{4 6 7}$ & $\mathbf{1 0 0}$ \\
\hline
\end{tabular}

The slant or direction of anti-corruption stories during the two eras is presented on Table 6. Out of 114 anti-corruption stories published during Obasanjo administration, 66 (57.9\%) were favourable, with an attention score of $198(70.72 \%) ; 17$ stories (14.91\%) with an attention score of $51(18.21 \%)$ were unfavourable; while $31(27.19 \%)$, with a score of $31(11.07 \%)$ were neutral. For Buhari era, 101 stories, representing 59.06\%, with an attention score of $303(64.88 \%)$, had favourable impact on the war against corruption; 47 (27.49\%), with attention score of 141 (30.19\%) were unfavourable; and $23(13.45 \%)$, with an attention score of 23 (4.93\%) were neutral. The neutral score was for stories that did not have strong positive or negative impression on the anti-corruption campaign.

Table-7. Considerations that influence the report of anti-corruption issues.

\begin{tabular}{l|l|l|l|l}
\hline \multirow{2}{*}{$\begin{array}{l}\text { Influences on Report of } \\
\text { Anti-Corruption Stories }\end{array}$} & \multicolumn{2}{l|}{ Obasanjo Administration } & \multicolumn{2}{l}{ Buhari Administration } \\
\cline { 2 - 5 } & Frequency & Average \% & Frequency & Average \% \\
\hline Economic & 26 & 22.81 & 57 & 33.33 \\
\hline Political & 61 & 53.51 & 73 & 42.69 \\
\hline Religious & 1 & 0.88 & 10 & 5.85 \\
\hline Social & 23 & 20.17 & 28 & 16.37 \\
\hline Tribal & 3 & 2.63 & 3 & 1.75 \\
\hline Total & $\mathbf{1 1 4}$ & $\mathbf{1 0 0}$ & $\mathbf{1 7 1}$ & $\mathbf{1 0 0}$ \\
\hline
\end{tabular}

Here, the considerations that influenced the report of anti-corruption issues by the sampled publications are assessed. During Obasanjo administration, stories with political consideration topped the bill with $53.51 \%$ from 61 stories; followed by economic consideration - 26 stories or $22.81 \%$, social $-23(20.17 \%)$, tribal - three $(2.17 \%)$, and religious - one $(0.88 \%)$. As for Buhari era, almost the same trend was recorded with political consideration also coming tops with $42.69 \%$, economic - second with $33.33 \%$, social - third, with $16.37 \%$, while religious $(5.85 \%)$ and tribal $(1.75 \%)$ swapped fourth and fifth positions. 


\section{Discussion of Findings}

The first objective set for this paper was to determine the frequency and prominence given to the coverage of anti-corruption campaign in Nigeria by the print media. Among all the editorial matters published on anti-corruption by the media, news stories, features and pictures/cartoons/drawings took the leading position. Also, placing $88.26 \%$ and $67.77 \%$ of their anti-corruption stories on the front/cover pages as well as the sectional/back pages during the Obasanjo and Buhari administrations respectively depicts the high prominence the media gave the issue. Apart from the position of placement, the media allotted full and half pages for anti-corruption stories with 98.21\% during Obasanjo era and 80.2\% during Buhari era. Besides, the media used adequate photographs, drawings, cartoons and other illustrations which, according to Ferguson and Pattern (1986) add depth and meaning to information published in the media by giving the readers "the essence of a situation at a glance." In this regard, the media published $89.19 \%$ of the illustrations on full pages, half pages and across three columns during Obasanjo administration while only 40.54\% were used during Buhari's.

These analyses are in concert with the position of McCombs and Shaw (1972) as cited in James and Akintunde (2018) that, "The media attach certain weights to news stories through placement, size and frequency of appearance of such stories." What this connotes is that the media have helped to place anticorruption in the public agenda. For, as Shaw (1979) expresses, the media, by focusing repeated and major attention on an event or set of related events, issues and persons can determine the importance people attach to public matters. Anti-corruption, in line with the agenda-setting theory used for this study, has become an issue in Nigeria largely because the media have aided to place it there.

However, Wilson (1997) warns that too much exposure to the same media content "brings about narcotisation, privatisation and apathy on the part of the audience." Narcotisation here means an effect that is proportionate to the kind of effect narcotics has on the human system that induces inactivity or passivity. This does not mean that the media agenda cannot influence the public's agenda. For as Udoakah (1998) posits, the press can only achieve the result expected of it if given the right base to perform while the Government should carry out its duty "through the provision of the basic needs of the citizens."

The second objective was to find out the extent to which the selected print media treated anti-corruption issues in their coverage. To discuss this, two issues came to play. First, the editorial contents were assessed under five broad categories of anti-corruption - bribery, forgery/perjury, fraud, misappropriation, and mismanagement. Media coverage during the tenure of Obasanjo placed mismanagement (33.33\%) and fraud $(31.58 \%)$ far above other categories. For the Buhari administration, fraud (35.67\%) came first and mismanagement (34.5\%), second. However, bribery took the last position during the two administrations.

The bottom-level coverage given to bribery is because this vice tends to occur in secret. As espoused by Rubio (2018) the chair of Transparency International, at the World Economic Forum (WEF) on Latin America held in March 2018, "Corruption is like the tango; you need two to dance. In each corrupt agreement, there is ... the one demanding or accepting bribes and the other paying or offering them." To, therefore, fight it successfully, Jeff Lovitt, a Berlin-based spokesman for Transparency International, quoted by O'Rourke (2002) admits, "It is increasingly clear that overall transparency is the most conducive thing to fighting bribery...." The mass media have a serious role to play in winning this fight against corruption in Nigeria.

The next issue here is the slant or direction of coverage given to anti-corruption issues by the print media during the two administrations. The attention scores obtained indicated that for the Obasanjo era, the media coverage of anti-corruption stories were $70.72 \%$ favourable, $18.21 \%$ unfavourable and $11.07 \%$ neutral, while for Buhari's, they were $64.88 \%$ favourable, $30.19 \%$ unfavourable and $4.93 \%$ neutral.

A situation whereby the media reportage could record an unfavourable slant of $30.19 \%$ during the Buhari era and $11.07 \%$ neutral for Obasanjo needs a little more analysis. According to Durverger (1972) information media in a capitalist society, when faced with "topics that are controversial, important or dangerous" and which have the capacity of "alienating part of their public and driving it away," tend to avoid such topics or handle them with the greatest precaution "in an attempt to satisfy everyone... thereby diverting public attention from it." The media here might, therefore, have acted based on this Duverger's position by avoiding being too critical of some suspected corrupt officials so as not to step on their big toes. Be that as it may, with very high percentage of a favourable slant, the Nigerian media can be said to have fulfilled the people's expectation by placing the fight against corruption on their agenda.

The third objective was to determine what other influences affected the editorial consideration of the selected newsmagazines and newspapers in their coverage of anti-corruption campaign in Nigeria. To discuss this, five contemporary dimensions - economic, political, religious, social and tribal - were selected as possible influences on the media.

The media can be influenced economically since, as business enterprises, they are generally set up to survive in the turbulent economic climate and to break even. Politically, the media exist in a complex society where their political decisions can either make or mar them; and on this dimension, the Sean MacBride-chaired International Commission for the Study of Communication Problems vividly explains that "Communication, taken as a whole, is incomprehensible without reference to its political dimension... and cannot be resolved without taking into account political relationship. Politics, to use the word in the 'elevated' sense, has an 
indissoluble relationship with communication" (UNESCO, 1980). Religiously, the media, as is the case in Nigeria, can be influenced when their operators become too apologetic in the defence of their faith and by, therefore, allowing this to becloud their sense of journalistic objectivity. Socially, the media output can be influenced by the cultural values and social norms of the people the media exist to serve. And tribally, media decisions taken can be affected by where the decision-makers or those top government officials they tend to protect come from.

In the findings of this study, the media coverage of anti-corruption issues in Nigeria was influenced by all the considerations already mentioned herein. Political consideration was uppermost in both the Obasanjo and Buhari administrations, followed by economic and social. However, for Obasanjo era, tribal consideration was placed fourth and religious last, while in Buhari administration, religious consideration came fourth and tribal took the rear. This last bit needs more than a passing reference.

The late Nigerian head of state, General (Abacha, 1996) had observed that the country's press was polarised along regional, sectional or ethnic lines with every side "protecting" and "supporting" their kith and kin. Professor Adigun Ajagbe, quoted in Oso (2003) sees the Nigerian press as "a captive of sectional, sectarian and other particulastic (sic) constituencies in civil societies." Also, Galadima and Ehighe (2001) observe that whenever a religious issue of topical dimension is analysed, "one will see a glaring case of sectional, ethnic and religious biased coverage of events by the Nigerian press."

Therefore, if the media, during the Obasanjo era were influenced more by tribal than religious consideration, this can be understood since in Nigeria, the Lagos-Ibadan axis, which is the base of this former Nigerian president, has the highest concentration of media activities; and many prominent media owners come from the same Yoruba tribal pool as he. This scenario is summarised better in the observation by Oso (2003) that "what we have in the country is essentially a regional-ethnic media with some limited national circulation." However, the fact that media coverage during Buhari era has more religious and less tribal coloration may be as a result of the incumbent president's strong religious affiliation.

\section{Conclusion and Recommendations}

From the data obtained and presented, it can be concluded that apart from the issue of prominence, including the use of photographs/illustrations and distribution of length of anti-corruption stories which varied between the Obasanjo and Buhari administrations, the trend in other areas of print media coverage of the subject matter was identical. Also, the research findings confirmed that the mass media in Nigeria have given adequate attention to anti-corruption thereby conferring on it the status of a matter of great national importance. The agenda-setting theory used as the theoretical framework for this study has thus been strengthened.

In order for the fight against corruption in Nigeria to be more vigorously and successfully covered by the mass media, the following recommendations are made:

1. The current administration of President Muhammadu Buhari should learn from the pitfalls of its predecessors and be more purposeful, proactive and all-inclusive in its fight against corruption; and as the president promised during his inauguration, he should, indeed, fight the war "head on;"

2. Special courts, with enough judicial officers and powers, should be established to dedicatedly adjudicate on corruption cases in Nigeria;

3. The atmosphere of suspicion amongst law-enforcement agencies and anti-corruption bodies in the country should be eliminated by encouraging greater cooperation and information sharing;

4. The mass media, in performing their agenda-setting function, should give adequate and responsible coverage on anti-corruption issues since sensitisation requires consistent and persistent efforts in reminding the public of the issue at stake; and

5. All the media of communication - newspaper, magazine, radio, television, cinema, home video, billboard, social media, etc. - should be stimulated to join in an aggressive anti-corruption crusade in Nigeria.

\section{References}

Abacha, S. (1996). The media and our destiny. In New Nigerian. Kaduna: New Nigerian Newspapers.

Ader, C. R. (1995). A longitudinal study of agenda-setting for the issue of environment pollution. In Journalism and Mass Communication Quarterly, 72(2), 300-310.

Africa News. (2018). Buhari named as AU's anti-corruption champion. Retrieved from http://www.africanews.com/2018/01/29/buhari-named-as-au-s-anti-corrption-champion-the-morning-call/. [Accessed, February 28, 2018].

Akor, L. (2014). The transparency international and Nigeria's corruption perception index: Implications for sustainable transformation. Global Journal of Interdisciplinary Social Studies, 3(5), 37-43.

Ayodele, A. E. (2012). Media and anti-corruption crusade in Nigeria. Retrieved from https://odinkadotnet.wordpress.com/2012/11/17/media-and-anti-corruption-crusade-in-nigeria. [Accessed, March 22, 2018].

Cassata, M. B., \& Asante, M. K. (1979). Mass communication: Principles and practice. New York: John Wiley \& Sons.

Cohen, B. (1963). The press and foreign policy. New Jersey: Princeton University Press. 
Durverger, M. (1972). The study of politics. New York: Thomas Y. Crowell Company, Inc.

Ferguson, D. L., \& Pattern, J. (1986). Journalism today. Lincolnwood, IL: National Textbook Company.

Fink, C. C. (1996). Strategic newspaper management. Massachusetts: Allyn and Bacon.

Galadima, J. D. (2003). Mass media, corruption and violence in the Nigerian political system. In Nwosu, I. (Ed.), Polimedia: Media and politics in Nigeria. Enugu: ACCE.

Galadima, J. D., \& Ehighe, J. (2001). The press in Nigerian politics: An historical analysis of issues, and pattern of news coverage. The Nigerian Journal of Communications, 1(1), 62-73.

James, A. J., \& Akintunde, B. A. (2018). Influence of mass media on voting pattern in rural areas of Nigeria. Research Journal of Mass Communication and Information, 4(1), 27-36.

Macrea, D. (1982). Problems of the structure and evolution of the Romanian empire. Scientific and Encyclopedic Ed.

McCombs, M. E., \& Shaw, D. L. (1972). The agenda-setting function of mass media. Public Opinion Quarterly, 36(2), 176187.

McLuhan, M. (1994). Understanding media: The extensions of man. Cambridge: The MIT Press.

Next Edition. (2018). Ghost workers: FG saves N68bn on personnel cost. Retrieved from https://www.nextedition.com.ng/news/headline/ghost-workers-fg-saves-n68bn-personnel-cost/32007/. [Accessed, March 22, 2018].

O'Rourke, B. (2002). East/West: Nordic nation's top in anti-corruption, but are their methods exportable? Retrieved from www.rferl.org/nca/features. [Accessed, March 22, 2018].

Okon, P. E. (2004). Coverage of anti-corruption in Nigeria by the news and tell magazines (June 1999 - May 2002). An Unpublished Ph.D. Thesis Presented to the University of Uyo, Nigeria

Oso, L. (2003). Mass media and democracy: Enlarging the space. The Nigerian Journal of Communication, 2(1), 8-17.

Oyibode, A. (2017). Anti-corruption war: Is Buhari winning? Retrieved from https://www.naija.ng/908342-corruptionwar-president-buhari-made-impact-nigeria.html. [Accessed, March 24, 2018].

Rubio, D. F. (2018). Is Latin America at a turning point in the fight against corruption? Retrieved from www.transparency.org. [Accessed, March 16, 2018].

Shaw, E. F. (1979). Agenda-setting and mass communication theory. International Communication Gazette. Retrieved from www.journals.sagepub.com. [Accessed, March 16, 2018].

Signature, T. (2018). Whistle blowing: FG recovers N29.2bn. Retrieved from http://signaturetv.com.ng/news/headline/ghost-workers-fg-saves-n9-2bn/. [Accessed, March 22, 2018].

Touitou, T. C. (2016). Mass media: Veritable tool in curbing corruption for sustainable peace and development in Nigeria? International Journal of Management Sciences and Business Research, 5(9), 51-61.

Transparency International. (2016). Corruption perceptions index 2016 table. [Accessed, March 22, 2018].

Transparency International. (2017). Corruption perceptions index 2016 table. [Accessed March 22, 2018].

Udoakah, N. (1998). Development communication. Ibadan: Stirling-Horden Publishers.

UNESCO. (1980). Many voices, one world. Paris: The UNESCO Press.

Vanguard. (2018). Corruption in judiciary goes beyond bribery - CJN. Lagos: Vanguard Media Limited.

Watson, J., \& Hill, A. (1993). A dictionary of communication and media studies. London: Arnold.

Wilson, D. (1997). Communication and social action. Port Harcourt: Footstep Publication.

World Bank Group. (2017). 2016 ease of doing business index. Retrieved from https://www.worldbank.org. [Accessed, March 4, 2018].

Yusha'u, M. J. (2009). Coverage of corruption scandals in the Nigerian press: A comparative analysis of Northern and Southern newspapers. An Unpublished Ph.D. Thesis Presented to the, University of Sheffield, UK. 